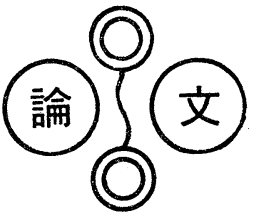

\section{低石炭化度炭の水分定量方法}

\author{
-1984. 4.12 受理一
}

日本鋼管秼 斉藤 陽, 田中 瑞雄, 宮津 隆*

\section{1. 緒言}

石炭の液化・ガス化あるいはコークス用原料炭に用 いる石炭の種類の範囲が広がるにつれて, 今後低石炭 化度炭についての性状を的確浪調することが必要に なるものと考光る。とくに分析試料水分の測定には JIS 規格にはない酸化雾团気の問題がある。

この種の石炭，すなわち褐炭類，巠れき青炭は，空 気雲困気中で 1 時間, $107^{\circ} \mathrm{C}$ で加熱, 乾燥する場合, 酸化による試料の質量增加のため, 重量法で測定する JIS 法1)では，水分含量が低目になることが以前より 知られていた2)。

昭和55年度（1980年）に工業技術院によって「石炭 類のJIS 規格とIS O 規格の整合性に関する調查研究」 が実施された時期に，褐炭類の水分定量法として，国 際的に標準化されていたのは共沸蒸留法3) のみであっ た。この方法はトルェンをたはキシレン中で試料を煮 沸して, 共沸蒸留により水分を直接測定するため, 酸 化の問題は除外できるので，基準法になりうる。共沸 蒸留法はJI S ${ }^{11}$ にも参考法として採用されているが， 受器の容積目盛の校正が必要なこと, 水と溶剤の界面 の分離状態が悪い場合に目盛の測定が困難なこと， た試料を多量 (100ｇ）飞使用することなど，いくつか の問題点がある。このことは褐炭類についての共沸蒸 留法の場合でる考慮しなければならない。

1981年にIS O事務局から，試料を N 2 ガス気流中で 加熱したさいに，離脱する水分を吸収剤で吸収する， 石炭についての直接重量測定法4 を褐炭類にも適用し たいとの提案 ${ }^{5}$ があった。さらに1982年には， N2ガス 気流中での加熱減量測定法による水分定量法6) ISO 事務局が推萀してきた。

本論文では低石炭化度炭について，直接重量測定法 と加熱減量測定法の 2 万法の検討を行った結果, 信頼 性の和ける分析方法を確立することができたので，こ

中央研究所 川崎市川崎区南渡田町 1-1

* 日科技連サンプリング研究会

石炭・コークス分析專門部会主査
れらについて報告する。な和直接重量測定法と炭素・ 水素元素分析法を組み合わせて，同一試料を用いて， 水分，炭素，水素を逐次分析する方法を考案したので 併せて記述する。

\section{2. 実験方法}

2.1 直接重量測定法

$0.2 \mathrm{~mm}$ 以下の石炭試料約 $1 \mathrm{~g}$ を, $105 \sim 110^{\circ} \mathrm{C}$ の乾燥 $\mathrm{N}_{2}$ ガス (含酸素量, $30 \mathrm{ppm}$ 以下) 気流中で一定時間 （れき青炭では 60 分間で十分）加熱し，離脱した水蒸 気を過塩素酸マグネンウム（アンヒドロン）に吸収さ せて科量し，その質量增加より水分值を求める。ただ し 30 分毎の重量增加が $0.2 \mathrm{mg}$ を越光なくなるまで加 熱操作を続行する。な招 $\mathrm{N} 2$ ガスの流速は, 乾燥器内が 60分間化15回ガス置換するようと調節する。

本実験に使用した装置を Fig.1 亿示す。石英管を用 い, 試料ボートを装入し, 加熱部分は二重管ジャケッ トで $107 \pm 2^{\circ} \mathrm{C}$ 亿保持する。この二重管ジャケットの内 部には，ポリエチレングリコール400を入れ,リボンヒ ーターをマゴコン・サーモレギュレーターを用いた温 度制御装置の出力側につないで規定温度に制御する。

試料の加熱㐾より発生した水蒸気を含む導入ガスは 石英管内の加熱領域を経由して，アンヒドロン吸収び んに導かれる。本実験では不活性ガスとして高純度 $\mathrm{N}_{2}$ ガスあるいは He ガスを使用した。

2.2 加熱隇量測定法

$0.2 \mathrm{~mm}$ 以下の石炭試料 $1 \sim 2 \mathrm{~g}$ を質量既知の科量び

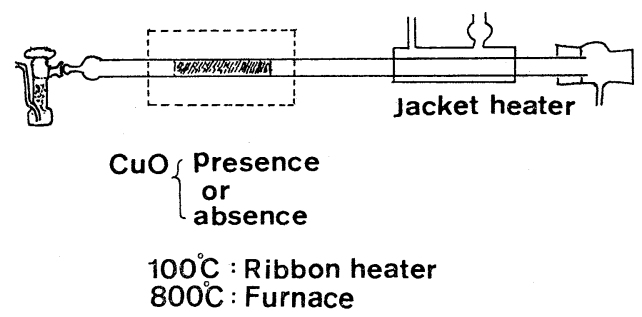

Fig. 1 Apparatus for determination of moisture of coal by direct gravimetric method 
えにはかりとり，105〜110 Cに保たれている水分括よ び酸素を含まない (30ppm以下) $\mathrm{N}_{2}$ ガスの雾囲気中で 60 分間乾燥し，その質量隇量より水分を求める。ただ 乙 30 分每の科量差が $1 \mathrm{mg}$ 以下になるまで乾燥を繰返 す。なお $\mathrm{N} 2$ ガスの流速は, 乾燥器内が 60 分間に 15 回置 換するように調節する。

本実験に使用した装置をFig.2 亿示す。ガス置換を 考慮すると, 装置の内容積は小さいことが望ましいの で，1980年に工業技術院の委託で行示れた「石炭類の JIS 規格と I S O 規格の整合性に関する調査研究」の さいに，水分定量用として提案されたアプデルハルデ ン (Abderhalden) の装置 る，科量びん 3 個を装入 できるように改造して大きくした。

Fig.2に示した二重管（乾燥室）の下部と連結した 丸底フラスコに,トルエンを入れて加熱し沸騰させる。 発生蒸気は二重管の外管と内管の間を経由して, 上部 の還流冷却管に上り，ここで冷却されて凝縮し，冷却 管の下部の導管を通って下方の丸底フラスコ内に液滴 となって落下する。二重管の部分のトルエンの蒸気が 凝縮しない上らに, 外部をりボンヒーターで保温する。 また導入ガスは二重管の乾燥室に取付けられているガ ラス管を通して加熱したのち乾燥室の奥で吐出させ, 試料から発生する水蒸気を含んだのち出口から排出さ せる。

分析操作としては，試料 $1 \mathrm{~g}$ を雬量びんにはかり取 り, 硝子板の台の上に乗せ, 二重管の乾燥室に装入し, 導入ガスとしてHeを使用し， $150 \mathrm{~m} \ell / \mathrm{min}$ の流速で 60 分間導入する。科量びんを取り出し，ふたをしてデシ ヶーターに入れ，20分間冷却したのち科量し，乾燥減 量から水分値（\%) を求める。

\section{3. 結果ならびに考察}

\section{1 直接重量測定法}

「石炭類の JIS 規格と I S O 規格の整合性に関する 調查研究」についての共同実験に打ける，れき青炭の 水分定量法の結果8) は, Table 1 亿示すように直接重 量測定法はJIS 法 ${ }^{1}$, 共沸蒸留法3)の 2 方法に比較する と，三池炭を除いていずれも C V $(\%)$ ，すなわち変動 係数が大きく，分析精度が劣っていることが明らかで ある。このことは水分含量の多い褐炭類，亜れき青炭 なぞの低石炭化度炭についても同一の傾向にあるもの と考觉られ。

共同実験を行ったさい，同実験に参加した12分析所 中 4 分析所から, 規定の $0.2 \mathrm{mg}$ 以下に吸収剂を恒量化 することは困難であるとの指摘があり，2 回の恒量化 操作の質量差が約1.3〜2.3mg专ると報告されている。

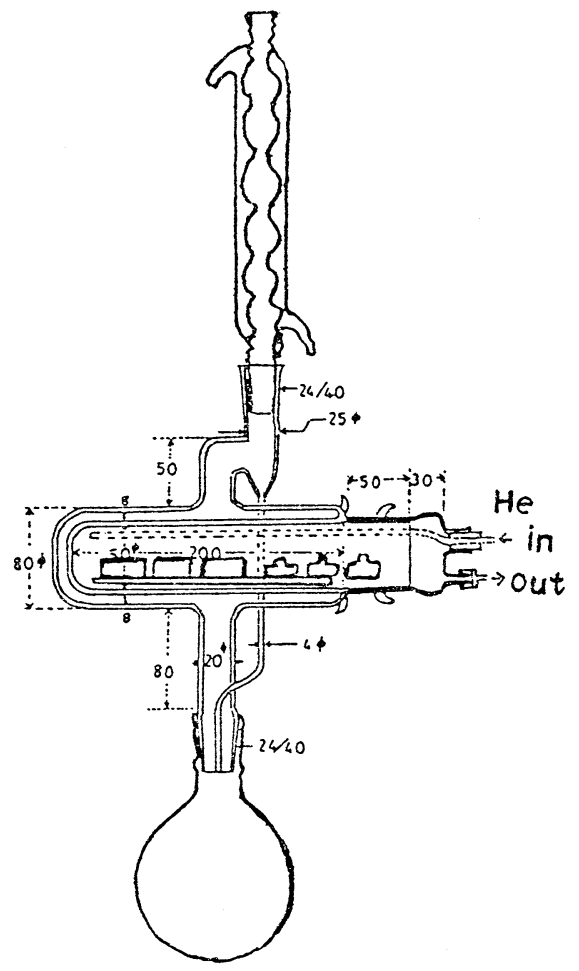

Fig. 2 Modified apparatus of Abderhalden's drier

吸収剂の恒量化が困難であれば，直接重量測定法に よる分析精度が劣った結果を示すのは当然のことであ る。

\section{1 .1 吸収剤の酸素ガスの吸着}

本法に打けるIS O 規格4)では, $\mathrm{O}_{2}$ ガス含量 $30 \mathrm{ppm}$ 以下の $\mathrm{N}_{2}$ ガスの使用を規定している。導入ガス量 200 $\mathrm{m} \ell / \mathrm{min}$ ，加熱時間 60 分とすると，導入 $\mathrm{N}_{2}$ ガス中に 含まれる $\mathrm{O}_{2}$ ガスの総量は， $\mathrm{O}_{2}$ が $30 \mathrm{ppm}$ で $0.51 \mathrm{mg}$ (0.36m $)$, five nineの高純度ガスで $0.17 \mathrm{mg}(0.12 \mathrm{~m} \ell)$ なので，分析操作時に空気の排気が十分行われていれ ば，導入ガス中の $\mathrm{O}_{2}$ ガスの吸着は本来問題にならな w。

したがって吸収剤の恒量化が得られない原因は, 試 料装入時に拈ける空気の混入による $\mathrm{O}_{2}$ ガスの吸着に よるものと推定した。この理由は筆者ら99が行った石 炭類 特よびュークス類の C, H 元素分析方法の検討の さいに得た知見に基づいている。JIS 法 ${ }^{10}$ 亿規定して いる $\mathrm{C}, \mathrm{H}$ 元素分析方法では， $\mathrm{O}_{2}$ ガス気流中で試料を 燃焼することによって発生した $\mathrm{H}_{2} \mathrm{O}$ および $\mathrm{CO}_{2}$ を， それぞれアンヒドロン和よびソーダアスベストの吸収 
Table 1 Precision* on determination of moisture in the analysis sample ${ }^{4}$ )

\begin{tabular}{|c|c|c|c|c|c|}
\hline & & Canmore & Balmer & Taiheiyo & Miike \\
\hline \multirow{2}{*}{$\begin{array}{c}\text { JIS M } 8812 \\
\text { Gravimetric method } \\
\text { (drying in air) }\end{array}$} & $\sigma_{\mathrm{E}}(\%)$ & 0.065 & 0.053 & 0.101 & 0.093 \\
\hline & $\mathrm{CV}(\%)$ & 4.00 & 4.53 & 1. 71 & 6.80 \\
\hline \multirow{2}{*}{$\begin{array}{c}\text { IS O } 331 \\
\text { Direct gravimetric method }\end{array}$} & $\sigma_{\mathrm{E}}(\%)$ & 0.169 & 0.103 & 0.185 & 0.083 \\
\hline & $\mathrm{CV}(\%)$ & 10.61 & 8.66 & 3.14 & 5.21 \\
\hline \multirow{2}{*}{$\begin{array}{c}\text { IS O } 348 \\
\text { Direct volumetric method }\end{array}$} & $\sigma_{\mathrm{E}}(\%)$ & 0.102 & 0.061 & 0.151 & 0.130 \\
\hline & $\mathrm{CV}(\%)$ & 6.55 & 5.50 & 2.45 & 9.39 \\
\hline
\end{tabular}

* Precision within same laboratory

Table 2 Results of determination of moisture in the analysis sample by ISO 331 method

(direct gravimetric method under a stream of nitrogen gas)

\begin{tabular}{|c|c|c|c|c|c|c|c|c|}
\hline & & \multicolumn{3}{|c|}{ Air is mixed partially, $\mathrm{H}_{2} \mathrm{O}(\%)$} & \multicolumn{3}{|c|}{ Air-cut $\mathrm{H}_{2} \mathrm{O}(\%)$} & Diff. \\
\hline & & $\mathrm{X}_{1}$ & $\mathrm{R}$ & $\overline{\mathrm{X}}_{1}$ & $\mathrm{X}_{2}$ & $\mathrm{R}$ & $\overline{\mathrm{X}}_{2}$ & $\overline{\mathrm{X}}_{1}-\overline{\mathrm{X}_{2}}$ \\
\hline \multirow[t]{2}{*}{ Yallourn } & 1 & 11.17 & \multirow{2}{*}{1.47} & \multirow{2}{*}{11.90} & 10.30 & \multirow{2}{*}{0.54} & \multirow{2}{*}{10.57} & \multirow{2}{*}{ 1. 33} \\
\hline & 2 & 12.64 & & & 10.84 & & & \\
\hline \multirow[t]{2}{*}{ Morwell } & 1 & 11.91 & \multirow{2}{*}{0.95} & \multirow{2}{*}{11.44} & 10.66 & \multirow{2}{*}{0.77} & \multirow{2}{*}{10.28} & \multirow{2}{*}{1.16} \\
\hline & 2 & 10.96 & & & 9.89 & & & \\
\hline \multirow[t]{3}{*}{ Taiheiyo } & 1 & 7.54 & \multirow{2}{*}{1.47} & \multirow{2}{*}{6.80} & 5.73 & \multirow{2}{*}{0.22} & \multirow{2}{*}{5.84} & \multirow{2}{*}{0.96} \\
\hline & 2 & 6.07 & & & 5.95 & & & \\
\hline & & $\overline{\mathrm{R}}$ & 1. 30 & & & 0.51 & mean & 1. 15 \\
\hline
\end{tabular}

郕に吸收させ, その重量增加より, 水素, 炭素を定量 する。リービッヒ法10)は吸収後の恒量化操作は不要で あるが, シェフィールド高温法10)和よび筆者らが開発 したリービッヒ改良法9）では，吸収後，吸収びんに乾 燥空気あるいは $\mathrm{O}_{2}$ ガスを導入する恒量化操作が必要 である。これはリービッヒ法では $\mathrm{O}_{2}$ ガスの流量が30〜 $40 \mathrm{~m} \ell / \mathrm{min}$ 小五るるに対して, 後者の 2 方法は $\mathrm{O}_{2}$ 流量が $300 \mathrm{~m} \ell / \mathrm{min}$ 以上であり，高温ガスの流量が大 で，吸収剤に持ち込まれる熱量が大きいため， $\mathrm{O}_{2}$ ガ スの吸 (脱) 着現象が起り, $\mathrm{O}_{2}$ ガスによる恒量化操 作が必要になる。吸収剂に持ら达まれる熱量は，計算 上では, シェフィールド高温法の場合, 約 $1000 \mathrm{cal}, リ$ 一ビッヒ改良法の場合，約700calになる。物理吸着は 固体表面と吸着媒分子の間に van der waals 力に似 た力が働くことによって起り，その吸収エネルギーは 数百ないし数千cal 程度といわ秃ている ${ }^{11)}$ ので, $\mathrm{O}_{2}$ ガ スの吸 (脱) 着現象は起りらる。

さらに筆者らはリービッヒ改良法の場合でも, 吸収 剤であるアンヒドロン执よびソーダアスベストに，湿
分の除去が不十分な空気を通した場合，あるいは塵芥 試料の然焼のさいに発生する微量のりん酸分がピロり ん酸あるいはメタりん酸の形で蒸気となって通過する 場合に，両吸収剂の恒量化が得られなくなることを認 めた ${ }^{12)}$

上記のことより，直接重量測定法による水分定量の さいには，湿ったガスの導入でアンヒドロン吸収剤が 活性化されることを意味するから，導入ガスの熱量が より少なくても， $\mathrm{O}_{2}$ ガスの吸着問題が起ることを考 慮すべきであろら。

\section{1 .2 空気の混入と吸収剂の重量変化}

Fig.1 に示した装置に扣いて，加熱炉と酸化銅の充 填層を取り除いて, 試料装入前に $\mathrm{N}_{2}$ ガスによる装置内 の空気排除を行わなかった場合と空気排除を行った場 合の実験結果をTable 2 に示す。本実験に用いた 3 銘 柄の試料について, 平均值を比較すると, 前者は後者 に対して $1.15 \%$ の高值を示している。これがすべて $\mathrm{O}_{2}$ ガスの吸着によるものとすると, 試料 $0.2 \mathrm{~g}$ に対し て $\mathrm{O}_{2}$ ガス約 $1.6 \mathrm{~m} \ell\left(\div 0.2 \times 1.15 \times 10^{-2} \times 22.4 \times 10^{-3} \times\right.$ 
Table 3 Results of determination of moisture in the analysis sample $\mathrm{H}_{2} \mathrm{O}(\%)$

\begin{tabular}{|c|c|c|c|c|c|c|}
\hline & & \multicolumn{2}{|c|}{$\begin{array}{l}\text { (ISO 331) } \\
\text { Direct gravimetric method }\end{array}$} & & \multicolumn{2}{|c|}{ JI S M 8812} \\
\hline & & \multicolumn{2}{|c|}{$\begin{array}{l}\text { without } \mathrm{CuO} \text {-heated zone under } \\
\text { stream of } \mathrm{He} \text {-gas }\end{array}$} & & \multicolumn{2}{|c|}{$\begin{array}{l}\text { Gravimetric method } \\
\text { (drying in air) }\end{array}$} \\
\hline & & $\begin{array}{l}\text { (1) under passing } \\
\text { of } 800^{\circ} \mathrm{C} \text { zone }\end{array}$ & $\begin{array}{l}\text { (2) under passing } \\
\text { of } 100^{\circ} \mathrm{C} \text { zone }\end{array}$ & & $\begin{array}{l}\text { run in parallel } \\
\text { with (1) }\end{array}$ & $\begin{array}{l}\text { run in parallel } \\
\text { with }(2)\end{array}$ \\
\hline \multirow{4}{*}{ Yallourn } & 1 & 12.98 & 13. 08 & 1 & 10.13 & 10.80 \\
\hline & 2 & 10.54 & 11.58 & 2 & 10.17 & 10.91 \\
\hline & $\overline{\bar{X}}$ & 11.76 & 12. 38 & $\bar{X}$ & 10.15 & 10.86 \\
\hline & $\mathrm{R}$ & 2.44 & 1.50 & $\mathrm{R}$ & 0.04 & 0.11 \\
\hline \multirow{4}{*}{ Morwell } & 1 & 10.19 & 10.66 & 1 & 8. 31 & 8. 61 \\
\hline & 2 & 9.19 & 10.95 & 2 & 8.37 & 8.92 \\
\hline & $\bar{X}$ & 9.69 & 10.80 & $\bar{X}$ & 8. 34 & 8.76 \\
\hline & $\mathrm{R}$ & 1.00 & 0.29 & $\mathrm{R}$ & 0.06 & 0.31 \\
\hline
\end{tabular}

1/32）に相当する。な和前者の 2 回の繰返しの差の平 均值は $1.30 \%$ で, 後者の繰返しの差 $0.51 \%$ 2. 6 倍に 達した。前者の繰返しの差が大きいのは, $\mathrm{O}_{2}$ の吸着 と脱着が交互に起り,な和から吸着が脱着よりも優先 するものと推定できる。

この実験結果は，直接重量測定法で水分を定量する さいに，吸収剤の十分な恒量が得られない原因のひと つとして, 分析操作時に装置内に混入する空気中に存 在する $\mathrm{O}_{2}$ の吸着が重要な因子であることを示してい るものと考光る。

\section{1 .3 酸素ガスの吸着に対する恒量化対策}

直接重量測定法で水分を定量するさいに，空気が混 入すると，アンヒドロン吸収剤の恒量化に難点がある ことが明らかとなった。この対策として下記の事項が 考えられる。

酸素を含有しない不活性ガスで空気を完全に排除し てから試料ボートの加熱が可能な装置, 操作を規定す るか，あるいは石英管内に約 $500^{\circ} \mathrm{C}$ に加熱した金属銅 の領域を設け， $\mathrm{O}_{2}$ ガスが混入しても，これを完全に除 去する方法が考えられる。ただし金属銅使用の場合に は，生成した酸化銅を水素還元で金属銅に再生する必 要がある。数多くの試料を分析するにつれて，還元操 作を頻繁に行う必要が生じ，これが日常操作では煩雑 な問題になる。一方, 石炭の $\mathrm{C}, \mathrm{H}$ 元素分析では, 分 解生成物を完全然焼させるために， $800^{\circ} \mathrm{C}$ に加熱した 酸化銅の領域を通過させるが，この場合 $\mathrm{H}_{2} \mathrm{O}$ の吸収に ついては問題点はない。また酸化銅は長期間に亘って 使用できる。筆者らはこの利点に着目して，酸化銅の 検討を試みた。ただし 3.1.1 で指摘した吸収前のガス
温度が $\mathrm{O}_{2}$ ガスの吸着に影響することを考虑しなけれ ばならない。

（1）加熱した酸化銅の領域を用いない場合

Fig.1に括ける二重管ジャケットの加熱部で，試料 を $107^{\circ} \mathrm{C}$ に加熱して発生した水蒸気を含む不活性ガス (He）を，同図の点線で囲った箇所を酸化銅は充填せ ずに, 電気炉で $800^{\circ} \mathrm{C}$ に加熱して通過させた場合と, 同䇢所をリボンヒータで $100^{\circ} \mathrm{C}$ に加熱した状態で通過 させた場合の比較実験の結果を Table 3 に示す。

この実験では水分吸収後, 取りはずした吸収瓶に恒 量化のため, 乾燥 $\mathrm{O}_{2}$ ガスを $200 \mathrm{~m} \ell / \mathrm{min}$ の割合で15分 間流している。

いずれの銘柄の試料の場合でも，直接重量測定法に よる水分值は, 並行して行ったJIS 法による值と比較 して高值を示した。

一方，Fig.3にみられるように，2 回の繰返しの測定 值の差は, $800^{\circ} \mathrm{C}$ の加熱領域を通した場合の方が， 100 ${ }^{\circ} \mathrm{C}$ 加熱領域を通した場合よりも大きい。このことは

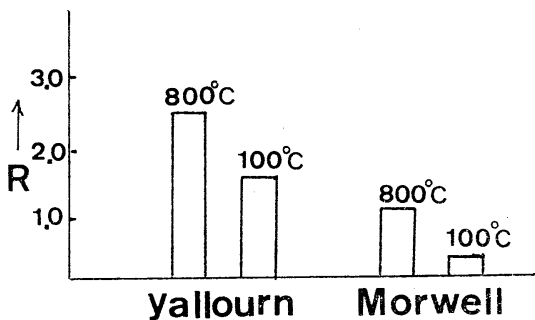

Fig. 3 Difference $(R)$ between two single results of moisture under stream of heated gas 
Table 4 Results of determination of moisture in the analysis sample by improved direct gravimetric method

\begin{tabular}{|c|c|c|c|c|}
\hline & & $\begin{array}{c}\text { Direct gravimetric method, with } \\
\text { CuO-heated zone under stream of He gas }\end{array}$ & $\begin{array}{c}\text { JIS M } 8812 \\
\text { (run in parallel with direct } \\
\text { gravimetric method }\end{array}$ & Diff. \\
\hline \multirow{2}{*}{ Yallourn } & \multirow{2}{*}{$*$} & 24.03 & 23.15 & 0.88 \\
\hline & & 23.54 & 22.83 & 0.71 \\
\hline \multirow{4}{*}{ Morwell } & 1 & 12.25 & 11.63 & \\
\hline & 2 & 12.37 & 11.49 & \\
\hline & $\bar{X}$ & 12.31 & 11.56 & 0.75 \\
\hline & $\mathrm{R}$ & 0.12 & 0.14 & \\
\hline \multirow{4}{*}{ Taiheiyo } & 1 & 6.18 & 5.64 & \\
\hline & 2 & 6.23 & 5.58 & \\
\hline & $\overline{\mathrm{X}}$ & 6.20 & 5.62 & 0.58 \\
\hline & $\overline{\mathrm{R}}$ & 0.05 & 0.06 & \\
\hline \multirow{4}{*}{ Balmer } & 1 & 0.64 & 0.70 & \\
\hline & 2 & 0.65 & 0.65 & \\
\hline & $\bar{X}$ & 0.64 & 0.67 & -0.03 \\
\hline & $\overline{\mathrm{R}}$ & 0.01 & 0.05 & \\
\hline
\end{tabular}

* analysis is performed at different day

$800^{\circ} \mathrm{C}$ の方が導入熱量が高く, 吸収剂の酸素吸 (脱) 着 が強く影響するために, 前者の 2 回の繰返しの測定値 の差が大きくなる原因であると推定でさる。

（2）加熱した酸化銅の領域を用いる場合

Fig.1に示した電気炉の石英管内に酸化銅を充填し， この部分を $800^{\circ} \mathrm{C}$ 加熱して特いて, 試料を $107^{\circ} \mathrm{C}$ 加 熱して発生した水蒸気を含も $\mathrm{He}$ ガスを通過させたの ら吸収剂に水分を吸収させ，ついで吸収びんをとり外 してこれに乾燥 $\mathrm{O}_{2}$ ガスを導入して恒量化を行った。 この方法による水分の定量結果を Table 4 に示す。

本実験では繰返しの精度は向上し, 並行して実施し たJIS法による分析値の繰返し精度と同程度であっ た。またこの方法で得た水分定量値はJIS 法による定 量值に比較して, ヤルーン炭とモーエル炭で, それぞ れ約 $0.8 \%$, 太平洋炭で0.6\%高い值を示したが，れき 青炭のバルマー炭ではー0.03\%で分析誤差内で一致し た。

前項の実験で，加熱した酸化銅の領域を用いない場 合には 2 回の繰返し測定の差が大きいのに対して, 加 熱した酸化銅の領域を用い場合には，繰返し精度は高 く, 水分吸収後の吸収剤に乾燥 $\mathrm{O}_{2}$ ガスを導入するこ とにより恒量化が可能になったことを示している。す なわち試料から発生した水蒸気を含も He ガスを加熱
酸化銅の領域を通過させてから吸収剂に導入した場 合，吸収剤の活性化が起らなくなるものと認めた。こ の原因はよくわからないが，水蒸気を含む導入 $\mathrm{He}$ ガ スが加熱した酸化銅の領域を通過すると水蒸気が凝縮 しやすくなることと関係があるのではないかと思われ る。

以上の実験結果から直接重量測定法による水分の測 定に和けるアンヒドロンの恒量化対策として, $800^{\circ} \mathrm{C}$ に加熱した酸化銅が有効なことを認めた。

\section{1 .4 確立した水分定量方法 ${ }^{13)}$}

上述した実験結果に基づき, 直接重量測定法の改良 法として，下記の分析法を確立した。

(1) Fig.1に示すように，石英管の装入口側に試料 中の水分を発生するための加熱用二重管を取付け, 石 英管内部を $107^{\circ} \mathrm{C}$ に保持し, 一方石英管の出口側に管 状炉を設置し, 石英管内の酸化銅の領域を $800^{\circ} \mathrm{C}$ に加 熱する。この石英管の出口側に予め恒量化してあるア ンヒドロン吸收びんを取付ける。

(2) サンプル約 $1 \mathrm{~g}$ をボートにはかり取り，このボ 一トを $107{ }^{\circ} \mathrm{C}$ に保持した石英管内に装入する。ついで 乾燥 $\mathrm{He}$ ガス*1 (次頁) を $100 \mathrm{~m} \ell / \mathrm{min}$ の割合で 1 時間導 入する。

(3) 吸収びんを取外し，乾燥 $\mathrm{O}_{2}$ ガスを $200 \mathrm{~m} \ell / \mathrm{min}$ 
Table 5 Sequential analysis of moisture, hydrogen and carbon of low rank coal by improved method

\begin{tabular}{ccccc}
\hline & & $\mathrm{H}_{2} \mathrm{O}(\%)$ & $\mathrm{H}(\%)$ & $\mathrm{C}(\%)$ \\
$\mathrm{d} \cdot \mathrm{B}$
\end{tabular}

(Ref. value): Anal. value by The Coal Mining Research Centre, Japan

の割合で15分間導入して恒量化を行ったのち科量し, その増量分より水分值（\%) を求める。

\section{1 .5 水分亡炭素・水素の逐次分析法}

低石炭化度炭は水分含量が大きく，かつ保存時の䨌 囲気条件の変化により, 短時間にその含量は変動し, 炭素・水素の分析值に大きく影響する。この問題をよ り少なくする手段として，同一試料を用いて，本実験 で確立した水分定量法（直接重量測定法の改良法）を もとに，水分と炭素・水素を逐次分析する方法を検討 した。その結果は下記のと括りである。

分析方法はFig.4に示すように，筆者らが開発した リービッヒ改良法9)の C H元素分析装置の燃焼管の入 口側に，本実験に使用した加熱用の二重管を取付け， 然焼管内を $107^{\circ} \mathrm{C}$ に加熱する。燃焼管の出口には恒量 化ずみのアンヒドロン吸収びんを連結して取付ける。

燃焼管の $107^{\circ} \mathrm{C}$ に保持した䇢所に試料ボートを装入 し, $\mathrm{He}$ ガスを導入して, 試料から発生する水蒸気を 同伴させ，燃焼管の先の吸収びんに導入する。1時間 導入したのち, 取外した吸収びんに乾燥 $\mathrm{O}_{2}$ ガスを 200 $\mathrm{m} \ell / \mathrm{min}$ 割合で15分間導入し，恒量化をはかったの

*1 次節で引用した 鈴木ら ${ }^{16)}$ の指摘によれば, $\mathrm{He}$ ガスはN2ガスや Ar ガスより脱水速度が速いので，試 料中の水分が早く発生するから，直接重量測定法で， 低石炭化度炭の水分を測定するさい，試料の加熱時間 を1時間と規定する場合には，導入ガスとして Heを 用いるのがよいと考党らる。

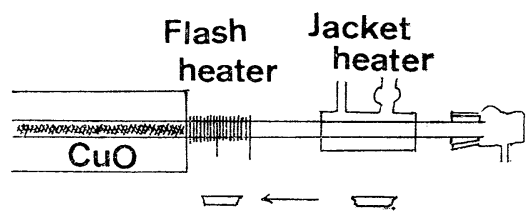

Fig. 4 Apparatus for sequential analysis of moisture, hydrogen and carbon of low rank coal

ら科量し，アンヒドロン吸収びんの質量の増加分より 水分 $(\%)$ を求める。ついで然燒管の先に, 別に準備 した恒量化ずみのアンヒドロンとソーダアスベストの 吸収びえを連結して取付け, 水分測定後の試料ボート をフラッシュヒーターの位監まで移動し, 通常の C H 元素分析を実施する。

この方法によれば，氷分定量值の分析精度は高く, また水分を定量したのちのサンプルで炭素・水素の元 素分析を寒施するため，水分補正はより正確になる。

Table 5 に 3 銘柄についての 分析結果を示すが，水 分, 水素, 炭素とも分析値の繰返し精度は良好であり, 水分值 (\%) を直接重量測定法4)で求め, リービッヒ 法で求めた炭素, 水素の分析值を無水ベースに換算し た基準值との間に偏差はみられない。

3.2 加熱減量測定法

3.2 .1 分析結果

れき青炭招よび褐炭などの 6 銘柄の試料について求 
Table 6 Comparison of anal. values of moisture (\%) by gravimetric method* and JIS method * based on calculation from the heating loss in mass of the coal under stream of He gas)

\begin{tabular}{|c|c|c|c|c|c|c|c|}
\hline & \multirow[b]{2}{*}{$\overline{\mathrm{R}}_{0}$} & \multicolumn{4}{|c|}{ Gravimetric Method* $\left(\mathrm{X}_{\mathrm{A}}\right)$} & \multirow{2}{*}{$\begin{array}{l}\text { JIS } \\
\text { Method } \\
\left(\mathrm{X}_{\mathrm{B}}\right)\end{array}$} & \multirow{2}{*}{$\begin{array}{c}\text { Diff. } \\
\overline{\mathrm{X}}_{\mathrm{A}}-\mathrm{X}_{\mathrm{B}}\end{array}$} \\
\hline & & $\mathrm{X}_{\mathrm{A} 1}$ & $\mathrm{X}_{\mathrm{A} 2}$ & $\overline{\mathrm{X}}_{\mathrm{A}}$ & $\mathrm{R}_{\mathrm{A}}$ & & \\
\hline Canmore & 2. 16 & 1. 77 & 1.84 & 1. 81 & 0.07 & 1.68 & +0.13 \\
\hline Balmer & 1. 38 & 1. 37 & 1.43 & 1. 40 & 0.06 & 1. 18 & +0.22 \\
\hline Miike & 0.75 & 1.88 & 1.95 & 1.92 & 0.07 & 1.59 & +0.33 \\
\hline Taiheiyo & 0.52 & 6.08 & 6.14 & 6.11 & 0.06 & 5.40 & +0.71 \\
\hline Yallourn & 0.35 & 31.03 & 31.07 & 31.05 & 0.04 & 30.46 & +0.59 \\
\hline Morwell & 0.29 & 12.76 & 12.79 & 12.78 & 0.03 & 11.97 & +0.81 \\
\hline
\end{tabular}

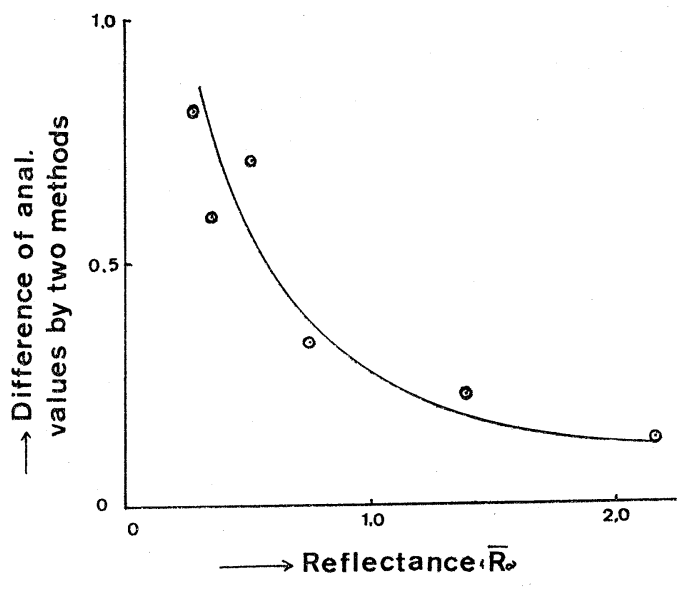

Fig. 5 Reflectance dependence of difference of anal. values of moisture by gravimetric method* and JIS method

(*under stream of $\mathrm{He}$ gas)
めた結果を，並行して行ったJIS 法（空気中加熱減量 測定法）の結果と併記して Table 6 亿示す。表からも 明らかなように, 本法で求めた水分定量値はJIS 法に よる水分定量值より高值を示した。Fig. 5 に Table 6 の試料の反射率と両方法に上る水分定量値の差の関係

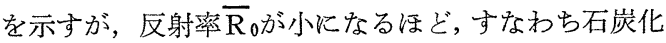
度が低いほどこの差は大になる。また 2 回の繰返しの 差の平均值は0.06であり, 繰返し精度は良好であった。

この加熱隇量測定法の提案に基づく共同実験の結果 14)の一部を Table 7 と引用する。

Table 7 のデータは, 9 分析所が, 4 銘柄の 低石炭化 度炭の水分を直接容量測定法と加熱減量測定法で分析 した結果である。表のデータはこれらの方法による水 分の分析值（\%) と並行して実施したJIS法による水 分の分析值（\%）との差を示している。直接容量法の 場合には，この差はすべてプラスであり，JIS法によ る水分定量值と比較して，何れも高值であることを示

Table 7 Bias on determination of moisture of low rank coal by different method (mean value of $\left(\overline{\mathrm{X}}_{\mathrm{i}}-\overline{\mathrm{J}}\right), \mathrm{J}$ : analytical value by JIS method)

\begin{tabular}{|c|c|c|c|c|}
\hline & $\begin{array}{l}\text { Taiheiyo } \\
\left(\overline{\mathrm{R}}_{0} ; 0.46\right)\end{array}$ & $\frac{\text { Beluga }}{\left(\overline{\mathrm{R}}_{0} ; 0.44\right)}$ & $\begin{array}{l}\text { Yallourn } \\
\left(\overline{\mathrm{R}}_{0} ; 0.30\right)\end{array}$ & $\begin{array}{l}\text { Morwell } \\
\left(\overline{\mathrm{R}}_{0} ; 0.30\right)\end{array}$ \\
\hline $\begin{array}{l}\text { Direct volumetric } \\
\text { method }^{* 1}(n=9)^{* 3}\end{array}$ & 0.493 & 0.342 & 0.359 & 0.699 \\
\hline $\begin{array}{l}\text { Gravimetric method*2 } \\
\text { under stream of } \mathrm{N}_{2} \\
\qquad(\mathrm{n}=9)^{* 3}\end{array}$ & 0.233 & 0.376 & 0.318 & -0.022 \\
\hline $\begin{array}{l}\text { Gravimetric method*2 } \\
\text { under stream of } \mathrm{He} \\
(\mathrm{n}=2)^{* 3}\end{array}$ & 0.635 & 0.870 & 0.855 & 0.915 \\
\hline
\end{tabular}

*1 by azeotropic distillation

*3 number of laboratory

$*_{2}$ based on the loss in mass in drying at $107^{\circ} \mathrm{C}$ 
している。また加熱減量測定法では， $\mathrm{N} 2$ ガスを導入し た場合に比較して，He ガスを導入した場合の方が差 が大きく高值を示した。

これに関連して，大沢の報告15)では，導入ガスとし て, 空気, $\mathrm{N} 2$ ガス, $\mathrm{He}$ ガスを用い, 導入時間を 1,2 , 3,4 時間と変光た実験で, Heガス導入のさいの水分 值が一番高值を示した。

この理由について鈴木ら ${ }^{16)}$ は, He は N2, Arなど他 の不活性ガスに比較して，熱伝導率敊よび拡散係数が 大きく，このため脱水速度が速くなり，試料中の水分 の発生が早く終了するためであると指摘している。

以上の検討内容からすれば，IS O事務局上り提案 されている方法6)で導入ガスを $\mathrm{N} 2$ ガスと規定している ことについてはさらに検討する必要がある。筆者らは 導入ガスとしては He ガスを採用する方法がよいと考 光る。

\section{3. $2.2 \mathrm{He}$ 気流中乾燥減量測定法 $133 * 2$}

以上の検討の結果，分析操作法をつぎのように規定 した。

(1) Fig.2 に示したアプデルハルデンの 改造装置の フラスコ内のトルエンが沸騰し, トルエンの蒸気が上 部の冷却器で凝縮し, その滴液が毎秒 $2 \sim 3$ 滴落下寸 るよら熱源を調節する。

(2) 試料約 $1 \mathrm{~g}$ を質量既知の乾燥容器に入れて表面 を平らにし，ふたをして質量を測定する。

（3）乾燥容器のふたを開き，乾燥室内に装入する。

(4) Heガスを $150 \mathrm{~m} \ell / \mathrm{min}$ の割合で乾燥室の一番奥 から吐出させ，水蒸気を含んだ排気ガスは手前から排 出させる。

（5）試料そう入時から60分間加熱する。

(6) 乾燥室から乾燥容器を取り出し，ふたをしてデ シケーターにいれる。

（7）冷却（20分以内）後，直ちに質量をはかって乾 燥減量を求める。

（8）水分值を算出する。

\section{4. 結語}

低石炭化度炭，とくに褐炭の水分定量法について I S O規格の直接重量測定法 おょよ゙加熱隇量測定法を 検討した結果，つぎのような知見が得られた。

（1）直接重量測定法；共同実験を行ったさいに，十 分の恒量化が得られないとの指摘があった。その原因

*2 本法は低石炭化度炭，褐炭類などを対象とした 水分定量法の「不活性ガス気流中乾燥減量測定法」と して，昭和58年度にJIS法として採用する方向で，日 科技連サンプリング研究会石炭・コークス専門部会で 検討が行われた。
は分析操作時に空気が混入すると, 吸収剂侸酸素が吸 着することに起因することが明らかとなった。この問 題点を解決し分析操作が容易で, 繰返し精度のよい改 良法を確立した。

改良法; 試料から発生した 水蒸気を含んだ導入 $\mathrm{He}$ ガスを， $800^{\circ} \mathrm{C}$ 亿加熱した酸化銅の領域を通してから 吸収剂に導き,ついで水分吸収後の吸收びんに乾燥 $\mathrm{O}_{2}$ ガスを導入することによって恒量化を行う。

な拉本法とリービッ七改良法を組及合わせた水分， 炭素，水素の逐次分析法を考案した。

（2）加熱減量測定法；不活性ガス導入下で，試料を 加熱乾燥し，その減量から水分を定量するが，導入ガ スは乾燥室内を 60 分間に 15 回置換するとの規定がある ので, 乾燥室容積の小さいアプデルハルデンの乾燥器 を改造して, 同時に 3 試料の測定が行兄る器具を採用 した。また導入不活性ガスとしては，熱伝導率および 拡散係数が大きく，したがって脱水速度の速い $\mathrm{He}$ ガ スが適していることを認めた。

（3）褐炭の水分定量結果は，直接重量測定法和よび 加熱減量測定法による分析值は，いずれもJIS 法によ る分析値より高い值になる。

（付記）

本実験を行うに当って助言をいただき，また基準值 となる分析值を出していただいた財団法人石炭技術研 究所 調查役, 大沢祥拡博士に感謝します。

\section{文献}

1) JIS M 8812 (1976)

2）日科技連サンプリング研究会資料，No.56, S C-149 (1954)

3) I S O $1015-1975(\mathrm{E})$

4) I S O $331-1975(\mathrm{E})$

5） I S O/T C 27N1327，1981，6.24（サンプリング 研究会資料, S C-81-71)

6）IS O/D I S 5068，1982，1.14(サンプリング研究 会資料，S C-82-49）

7) Abderhalden, E., Abd. biochem. Arb, I, 296 (1910)

8）日本科学技術運盟, 燃料協会「石炭類のJIS 規格 とIS O規格の整合性に関する調查研究」報告書 (1981)

9）斉藤 陽，石井照明，燃協誌， 58，203（1979）

10) JIS M 8813 (1976)

11) Moore, W. J., 藤代亮一訳, 物理化学(下) (東京 化学同人) p. 554 (1964)

12）斉藤 陽, 石井照明, 日科技連サンプリング研究 
会，原料・燃料の品質管理，Sess． III-07（1981）

13）斎藤 陽, 田中瑞雄, 第19回石炭科学会議発表論 文集，p.93-97，1982年10月

14）日科技連サンプリング研究会資料，S C-83-11 (1983)
15）大沢祥拡，日科技連サンプリング研究会資料， S C-83-73 (1983)

16）鈴木孝平，大野 允，鬼島 昭，日科技連サンプ リング研究会資料, S C-83-2（1983）

\title{
Determination Method of Moisture in Low Rank Coal
}

\author{
Kiyoshi SaIto*, Mizuo TANAKA*, Takashi MiYazU** \\ (* Technical Research Center, Nippon Kokan K. K. \\ $\left(\begin{array}{c}* * \text { Chairman of the Subcommittee for analysis of coal } \\ \text { and coke of Sampling Research Committee, JUSE }\end{array}\right)$
}

SYNOPSIS : - The low rank coal, especially brown coal has a highly hygroscopic and unstable property, so JIS method could not be applied to such a coal.

In direct gravimetric method we found that the cause of difficulity to get constant weight may be attributed to adsorption or desorption of oxygen gas and the passing of the inert gas containg the moisture brings about the activiation of absorber which also results the difficulity to get constant weight.

So we have established the improved gravimetric method to get correct value, which is comprised by two factors, one is passing of the inert gas containing moisture to heated copper oxide zone before the absorption of moisture by absorber, and the other is passing of the dry oxygen gas to absorber to get the constant weight.

The sequential analysis of moisture, hydrogen and carbon of brown coal was achieved by this improved method.

In drying method, we established the improved method comprised of using modified apparatus of Abderhalden's drier and introducing helium gas.

\section{Key Words}

Moisture in coal, Moisture determination of low rank coal,

Direct gravimetric method of moisture in low rank coal 